\title{
The Paradoxical Effects of Legal Intervention over Unethical Information Technology Use: A Rational Choice Theory Perspective
}

\author{
Mohamed-Hédi Charki \\ EDHEC Business School \\ mhc@edhec.edu \\ +33320154451
}

24 Avenue Gustave Delory, Roubaix 59057, France

Emmanuel Josserand

University of Technology Sydney

emmanuel.josserand@uts.edu.au

$+61295143606$

PO Box 123, Broadway NSW 2007, Australia

\author{
Nabila Boukef \\ ESDES School of Management - Catholic University of Lyon \\ nboukef@univ-catholyon.fr \\ +33625919172 \\ 10 Place des Archives Lyon Cedex 02, France
}

\begin{abstract}
While the IS literature offers rich insights into the kinds, causes and consequences of unethical information technology use (UITU), we know little on the degree to which legal intervention could mitigate UITU. Our research aims at understanding how legal intervention could mitigate UITU by influencing the cost-benefit analysis determining the decision to commit such UITU. Our contributions are twofold. First, we provide testable propositions on the role of legal intervention. Second, we offer an innovative take on intervention, where it is conceived as a multi-mechanism process that adapts to UITU as well as to evolutions in IT use.
\end{abstract}

Keywords: Unethical information technology use (UITU), rational choice theory (RCT), intervention, visibility, interpretive and case study. 


\section{Introduction}

While IT $^{1}$ use has provided huge economic and social benefits, these advantages have been tainted by UITU. Research suggests that UITU causes harm (Chatterjee et al., 2012) and leads to losses for business and society (Leonard and Cronan, 2001), and challenges for managers (Bush et al., 2010).

Accordingly, information systems and ethics scholars have called for a clearer understanding of concrete solutions on how to address UITU (Bush et al., 2010; Chatterjee et al., 2012; Stylianou et al., 2013). One of the solutions envisaged is intervention in the form of codes of conduct $(\mathrm{Oz}, 1992)$. However, there is evidence that management- or third-party-implemented codes of conduct are inefficient in regulating UITU (Harrington, 1996; Healy and Iles, 2002). Despite such evidence, there is still a dearth of empirical research exploring the extent to which other forms of intervention can remedy the problem. In particular, Gattiker and Kelley's (1999) call for the study of legislative intervention remains unanswered. Since intervention has been deemed effective (Jasperson et al., 2005) and shown to influence the ethics of decision-making (Bommer et al., 1987; Leonard et al., 2004), we pose the following research question: how can legal intervention mitigate UITU by influencing the cost-benefit analysis that determines the decision to commit UITU. For this purpose, we build on Gray (2008), and contend that intervention is a formalized enactment that a commonly agreed-upon third party develops in order to influence the behaviors of IT users in such a way as to ensure a specific course of action in line with the ethical norms of the larger community.

To pursue our aim, we borrowed the theoretical lens of RCT from the field of criminology. RCT provides a valuable framework for analyzing deviant behaviors such as UITU since it explores the contexts that inhibit or foster such behavior (Cornish and Clarke, 1986; McCarthy, 2002; Paternoster and Simpson, 1996). Given the exploratory nature of our investigation, we opted for a qualitative design rooted in an interpretive epistemological stance.

We purposefully selected the case of the ethically controversial technology of ORAs. Beall and his colleagues (2003) define an ORA as an "online, real-time dynamic auction between a buying organization and a group of pre-qualified suppliers who compete against each other to win the business to supply goods or services that have clearly defined specifications for design, quantity, quality, delivery, and related terms and conditions. These suppliers compete by bidding against each other online over the Internet, using specialized software by submitting successively lower priced bids during a scheduled time period" (Beall et al., 2003, p. 7). The technology provides a sensitizing empirical setting for our research question. Indeed, ORAs have been identified by academics (Charki et al., 2011; Emiliani, 2005), practitioners (Atkinson, 2003) and legal experts (Van Eecke and Skouma, 2006) as the technology that has led to the most serious unethical usages in information technology.

Our study offers two main theoretical contributions to the information systems literature. First, we provide testable propositions regarding the role of legal intervention, and discuss its expected complex and paradoxical effects on UITU and IT use more generally. According to the intervention being investigated, we also offer an innovative take on it as a dynamic, multimechanism process that can adapt to UITU as well as to the evolutions in IT use.

\footnotetext{
${ }^{1}$ We abbreviate the following terms in this paper: information technology (IT), unethical information technology use (UITU), rational choice theory (RCT), and online reverse auction (ORA).
} 


\section{Theoretical Background}

In this section, we further elaborate on the research gap by detailing why legal intervention might be an effective mode of intervention in relation to UITU and then presenting RCT, our theoretical lens for the empirical study.

\section{Intervention and UITU}

Jones (1991) provided one of the most widely used definitions of unethical behaviors: "a decision that is either illegal and or morally unacceptable to the larger community" (p. 367). The specific concept of UITU was first evoked in the information systems literature by Chatterjee (2005), who drew on the seminal work of Mason (1986) to suggest that UITU refers to the violation of one or more pillars associated with ethics in the information age: privacy, accuracy, property, and access. However, IS research deals with a broad range of UITU that falls within Jones's (1991) broader definition and includes computer abuse (Straub and Nance, 1990), software piracy (Moores and Chang, 2006), unethical use of sales technology (Bush et al., 2010), breaches of privacy and intellectual property (Stylianou et al. 2013), deceiving suppliers (Charki et al., 2011) and computer abuse in organizations (Straub and Nance, 1990). Accordingly, we define UITU as technology use that is either illegal or morally unacceptable to the larger community. This is consistent with definitions that describe unethical behaviors as abuse related to the use of IT (Straub and Nance, 1990).

In the context of organizations, intervention with respect to UITU often takes the form of business codes. ${ }^{2}$ In the case of IT use, business codes are seen as a necessary intervention to promote good business practices (Payne and Landry, 2005). Issued by IT managers or senior managers, they aim to clarify responsibilities (Johnson and Mulvey, 1995; Oz, 1992) and influence behavior (Leonard and Cronan, 2001). However, despite initial enthusiasm (Oz, 1992), prior research has indicated that they have a limited impact on UITU. Harrington (1996) found that both generic codes and specific IS codes in nine US-based organizations had no impact on computer abuse: employees lacked awareness of the codes or the codes were in conflict with sub-group norms. Healy and Iles (2002) concluded that business codes were ineffective in regulating UITU because ethical IT use was considered secondary to efficient operations by users.

However, while business codes have been shown to have a limited effect on UITU, we contend that the potential of legal intervention is more significant. Indeed, Gattiker and Kelley (1999) called on legislators to find ways to enforce intervention, notably in situations where UITU is not perceived by perpetrators as abusive. Indeed, legal intervention has been depicted as an important determinant in many ethical decisions (Bommer et al., 1987). Here, the power at the source of the intervention is also a key factor in its effectiveness (Jasperson et al., 2005). At the same time, legal intervention has been portrayed as particularly influential in determining ethical actions (Leonard et al., 2004) and unethical decisions (Bommer et al., 1987) through the rules and norms it enunciates.

\section{RCT as a theoretical lens}

The central premise of RCT (Cornish and Clarke, 1986; McCarthy, 2002; Paternoster and Simpson, 1996) is that the decision to commit a deviant act is understood as the outcome of a cost-benefit analysis by individuals who attempt to maximize their well-being as they

\footnotetext{
${ }^{2}$ The literature uses different terms, such as "code of conduct," "code of ethics," and "business code." In line with Kaptein and Schwartz (2008), we refer to this intervention mechanism as a "business code."
} 
compare the benefits of the deviant act with the cost of the penalties and social outcomes that may ensue (Paternoster and Simpson, 1996; Piquero and Hickman, 2002).

More precisely, McCarthy (2002) explains that a decision to offend on the part of selfinterested individuals is influenced by people's preferences, their attitude to risk, and their assessment of an illegal opportunity's availability, cost and benefits versus a legitimate opportunity's availability, cost, and potential for realizing the same or comparable returns. Taken together, these parameters influence the likelihood of a crime occurring. This likelihood is greater when the utility of the crime is greater than its associated costs. Conversely, the likelihood of a crime occurring will be lower when its costs outmatch its expected utility (Paternoster and Bachman, 2001).

Moreover, RCT theory delineates the different types of cost associated with crime in terms of punishment. These costs include legal sanctions (Nagin, 1998), economic costs such as loss of income (Grogger, 1991), and other costs such as guilt, shame (Grasmick and Bursik, 1990) and social rejection (Nagin, 1998). RCT suggests that crime can be prevented not by changing offenders but by changing aspects of the context in which offenses typically occur-in our case, by legal intervention.

Insights gained from RCT have already made a significant contribution to the information systems and security literature. For instance, Li, Zhang and Sarathy (2010) found that employees' intention to comply with an internet use policy is influenced more by the probability of an offense being detected than by the severity of the penalties likely to be imposed. In another example, Bulgurcu et al., (2010) found that employees' overall assessment of the consequences of abuse is based on their assessment of the benefits and costs of compliance and the cost of non-compliance; this assessment explains their attitude towards compliance with the organization's information security policy.

Building on this review of RCT in Criminology and its application in the IS literature, we contend that three main principles of RCT are fundamental to our analysis of UITU. First, offenders' actions are consistent with the maximization of their utility. This is assessed ex-ante as they weigh up and compare the costs and benefits linked to the deviant behavior in question. Second, the appraisal and resulting choices are made on the basis of imperfect information about both the costs and the benefits of the crime carried out in a context of uncertainty. Third, offenders make their decisions at individual level. Introducing RCT allows us to fine-tune our research objective. In order to understand how legal intervention could mitigate UITU, we build on interviews with the various actors to understand the extent to which legal intervention influences the cost-benefit analysis that determines the decision to commit such UITU.

\section{Methodology}

Numerous articles have exposed the extensive UITU linked to ORAs. These include allowing unqualified suppliers to bid, obliging suppliers to honor unfairly low bids, misrepresenting facts and phantom bidding, threatening incumbent suppliers with the choice of bidding or losing their contract, and including buyers as bidders (e.g., Charki and Josserand, 2008; Emiliani, 2005; Giampietro and Emiliani, 2007; Tassabehji et al., 2006).

In this paper, our research question examines how legal intervention can mitigate UITU. More precisely, our aim is to understand how legal intervention can influence the cost-benefit analysis that determines the decision to commit UITU. Given the exploratory nature of our 
question, a qualitative approach seemed to be a logical choice, particularly since the study examines real, hard-to-access data on unethical usage of IT associated with the very sensitive arena (Dickson-Swift et al., 2009) of buyer-supplier relationships, in which the financial stakes are high.

Qualitative designs are widely accepted in the information systems literature (Myers and Avison, 2002) and in situations where researchers need to capture rich and subtle patterns of complex detail in order to draw closer to the actors' interpretations (Denzin and Lincoln, 2011). For our purposes, we wanted to go beyond the perspective of IT users alone and to understand the world from the viewpoint of those studied (Pratt, 2009). More specifically, in order to make sense of our results, we used an interpretive approach (Walsham, 1995), since the interpretation of the effects of intervention is deeply entrenched in the actors' contexts and the subjective comprehension of ORA technology. Embedding this approach in a single casestudy design enabled us to grasp the ORA technology as a system of understanding of the social interactions between actors (Klein and Myers, 1999). Single case studies are well accepted in the information systems literature (e.g., Berente and Yoo, 2012; Sarker et al., 2012; Seidel et al., 2013). From an IT artifact standpoint, we examined ORAs from the "ensemble" view, in which the technology is embedded in a complex and dynamic social context (Orlikowksi and Iacono, 2001). This "ensemble" view incorporates the social influences that shape the way different groups engage with the technology, and in so doing it enables interpretive researchers to see reality as an inter-subjective construction of shared human cognitive construction (Walsham, 1995).

\section{Context}

As the principle of contextualization is highly important to facilitate understanding of the subsequent results (Klein and Myers, 1999), we present a detailed overview of our context, while positioning it in the realm of information ethics.

The field of information ethics has benefitted from increased scholarly attention in recent years due to the proliferation of a range of ethical challenges, such as information systems misuse (D'Arcy et al., 2009) and information security policy violation (Siponen and Vance, 2010). Notwithstanding the diversity of ethical challenges associated with the wide array of digital technologies, it is difficult to gather all forms of UITU in one unique empirical context. Accordingly, we decided to focus on an acute and revealing case of ORA technology, which we expected to prove interesting since it represents one of the most severe cases of UITU that exist. It provided us with the basis for a theoretical contribution that could make sense in other contexts of UITU.

Initially, ORA technology was hailed by its creators as being very useful for buyers and suppliers alike. It was presented to buyers as a means of widening their sourcing horizons (Daly and Nath, 2005), reducing administrative and logistical costs (Hur et al., 2007), and enhancing purchasing performance (Jap, 2003). Suppliers were told that it would provide access to new markets, compress time to market, and reduce transaction costs (Smart and Harrison, 2003).

From a technical standpoint, ORA technology is administered by an online market maker that provides a technical platform to host the online bidding event. In this case, the platform is called Agentrics. ${ }^{3}$ The most famous concept of an online auction is that of eBay, with an

\footnotetext{
${ }^{3}$ Agentrics was acquired by NeoGrid (https://www.neogrid.com/uk)
} 
online forward auction where a single supplier solicits ascending online bids from buyers. However, the ORA concept is based on what is known as a Dutch auction, in which a number of pre-selected professional suppliers are invited to an online auction by professional buyers. Prices are put forward in a descending manner until the best price (from the buyer's vantage point, i.e., the lowest bid) is reached, with no additional bids from other suppliers after the time limit. This practice has been used in virtually every major industry, including the retail and automotive industries (Jap, 2007).

Despite its initial promise, the ORA system was misappropriated and now bears the dubious honor of being the technology that is most widely associated with unethical IT use (Giampietro and Emiliani, 2007). This naturally triggered numerous negative reactions in the business press. The case is revealing because it is a morally intense issue with high stakes for the IT users (both buyers and suppliers) concerned (see Table 1 for details on UITU before, during and after ORAs).

Table 1. Review of UITU associated with ORAs (adapted from Emiliani, 2005, p. 527)

\begin{tabular}{|c|c|c|}
\hline Before the online bidding event & During the online bidding event & After the online bidding event \\
\hline $\begin{array}{l}\text { Ambiguous or shifting auction } \\
\text { rules }\end{array}$ & $\begin{array}{l}\text { Threatening incumbent suppliers to } \\
\text { bid or risk losing the work }\end{array}$ & $\begin{array}{l}\text { Contract terms and conditions } \\
\text { changed between request for } \\
\text { quote and award }\end{array}$ \\
\hline $\begin{array}{l}\text { Incomplete or inaccurate } \\
\text { specifications provided }\end{array}$ & $\begin{array}{l}\text { Identities of the bidders and their } \\
\text { bids revealed }\end{array}$ & Post-auction renegotiation \\
\hline \multirow[t]{4}{*}{$\begin{array}{l}\text { Unit prices driven down with no } \\
\text { intention of switching sources }\end{array}$} & $\begin{array}{l}\text { Unqualified suppliers allowed to } \\
\text { bid }\end{array}$ & $\begin{array}{l}\text { Only some portions of the items } \\
\text { in a bid package awarded }\end{array}$ \\
\hline & $\begin{array}{l}\text { Phantom bidding (buyer or market } \\
\text { maker pretends to be a supplier) }\end{array}$ & $\begin{array}{l}\text { Specifications relief given to } \\
\text { winning bidders }\end{array}$ \\
\hline & $\begin{array}{l}\text { Suppliers forced to honor } \\
\text { unreasonably low prices }\end{array}$ & $\begin{array}{l}\text { Repetitive re-bidding to drive } \\
\text { down prices }\end{array}$ \\
\hline & $\begin{array}{l}\text { Internal departments included as } \\
\text { bidders }\end{array}$ & Bidders not informed of outcomes \\
\hline
\end{tabular}

With regard to our research question, we noted that the practice of allowing unqualified suppliers, phantom bidders or even the buyers themselves to bid was the most commonly cited and damaging UITU for suppliers.

Our study was located in France where, as in other contexts, many anomalies had been noted in the use of ORA technology. As UITU had reached a considerably high level, the French government voted through the first legal intervention in June 2005 with the so-called Dutreil Law, which was published in August 2005 (Official Journal of the Republic of France No. $179,3^{\text {rd }}$ August 2005, page 12639, NOR: PMEX0500079L; see Appendix C). The law was implemented in France but was not followed up in the rest of the EU.

As some buying organizations tried to circumvent the legal intervention, the legislator intervened again in the same year (Official Journal of the Republic of France, No. 303, 30 December 2005, page 20557, NOR: PMEA0510001C) by introducing an amendment to deal with some of the loopholes identified in the first intervention (see Appendix D).

\section{Data collection}

As the topic investigated is highly sensitive and involves hard-to-disclose information, we drew upon a prior case of collaboration with a large French retailer to convince our key informant to grant us access to buyers and suppliers who had used the technology. 
Before beginning our interviews, we searched the French and European business press and legal publications in order to understand the whole story from the appearance of UITU through to the enactment of the legal intervention. We began data collection more than two years after the implementation of the law (in April 2008), a period when IT users developed their interpretations of the intervention and the extent of its usefulness. We gathered the data over an eight-month period from April 2008 until December of the same year.

Following an initial discussion about our research question with our key informant, we decided to interview buyers who had used the technology between early 2006 and April 2008, as we were initially interested in making sense of how the law can influence the cost-benefit analysis determining the decision to commit UITU. A majority of these informants had been using ORAs before the intervention or had heard stories about the extent of its use. These buyers would therefore be able to make better sense of the intervention. We began by interviewing the selected buyers. We also asked them to name at least one supplier with whom they had used ORA technology following the legal intervention. Our key informant also gave us access to the internal and external (market maker) initiators of the technology. This gave us access to difficult-to-obtain data.

At the same time, as interpretive researchers, we adopted a posture that preserved openness to the field data (Walsham, 1995); we saw IT as a system of social interactions that aimed at understanding sense-making by multiple stakeholders interested in the ORA technology (Hirschheim et al., 1995). Thus, we wanted access not only to those who used the technology (buyers and suppliers) but also to those who influenced the use of the technology directly (IT initiators). Furthermore, even though our goal was to understand the degree to which a legal intervention influences the cost-benefit analysis determining the decision to commit UITU from the vantage point of the focal IT users (buyers and suppliers), we also sought the perspective of other actors to gain a broader understanding of this complex issue. We thus included interviews with institutional actors and lawyers since they influenced and made sense of the intervention. Table A1 explains the roles played by each category of informant in detail.

In order to garner a comprehensive understanding of the question, we relied mainly on semistructured interviews. This type of interview is frequently used in information systems research, in particular to investigate under-researched topics so as to obtain information that may otherwise be hard to gather (Myers and Newman, 2007). Moreover, since we were dealing with a very sensitive issue, we knew that the use of narrative techniques (Chase, 2011) could be appropriate as they are particularly effective in conveying what actors cannot reveal directly to researchers. We thus relied on broad questions covering the main objectives of the interviews, letting informants present their own perspective. The main objectives of the interviews were:

a) to make sense of the way the use of IT is initially formalized and to understand the limits of this approach,

b) to explore the revisions fostered by the intervention and that influenced the sensemaking of our groups of informants, and thus the cost-benefit analysis determining the decision to commit UITU or not,

c) to search for any emergent and unexpected outcomes or evolutions associated with the intervention and/or with the ways in which users negotiate the technology and/or the intervention. 
Appendix A summarizes the data collected and the categories of informants interviewed. We interviewed 63 representatives from five categories of informants who had a direct or indirect role in framing the legal intervention and/or the interpretation of UITU: i.e., buyers, suppliers, IT initiators, key institutional actors who played leading roles in the crafting of the intervention, and key international legal experts in ORA technology.

On average, our interviews lasted 33 minutes with the buyers, 31 minutes with the suppliers, 48 minutes with the IT initiators, 55 minutes with the institutional actors, and 53 minutes with the lawyers. All of the interviews were recorded and then fully transcribed. In total, 689 pages of data were produced.

\section{Data analysis}

Our objective was not to test a positivist theoretical framework (Orlikowski and Baroudi, 1991) but rather to discover a new theoretical framework as it emerged from our data. This process, in line with the recommendation by Klein and Myers (1999), helped us to interpret the data so as to generate empirically embedded theoretical propositions and insights.

We carried out a code-based content analysis, which allowed us to analyze data by categorizing verbatim into meaningful sections and sub-sections. Although our study did not follow a grounded theory method, we opted for a three-stage process of open coding, axial coding, and selective coding. This approach is widely accepted in the information systems literature when mobilizing interpretive studies (see, for instance, Berente and Yoo, 2012; Henfridsson and Lind, 2014; Racherla and Mandviwalla, 2013). We used the N-vivo software package because of its elasticity, multiple coding potential through rich data, and information cross-referencing tools (Richards, 1999). Appendix B recapitulates the resulting first-order codes, second-order codes, and aggregated categories.

Our first phase of open analysis sought to unravel the high level categories of constructs. With our research question in mind, namely, understanding the extent to which the intervention was able to influence the cost-benefit analysis determining the decision to commit UITU, we examined interview transcripts line by line. Our main focus was on understanding how informants interpreted the effects of the law on the cost-benefit analysis determining the decision to commit UITU. All the excerpts that referred to the same unit of meaning were ascribed to a particular code (Miles and Huberman, 1994). Simultaneously, we tried to stay open to any potentially new and important constructs in our data. We pursued this process until we reached theoretical saturation, that is to say, until formerly identified constructs reappeared in the data (Corbin and Strauss, 2008) and we thus felt confident that the data had "earned their way" into the theoretical scheme (Morse, 2004). We also searched for potential contradictory statements between informants. As per our research objective, we found accounts of mechanisms explaining the potential impact of the law on existing UITU as well as some discrepancies between groups of actors whereby mechanisms were interpreted as efficient or not. All discrepancies were accounted for in the results section. Thanks to the open coding approach adopted, our data also revealed unexpected findings such as the emergence of new UITU, the broader impact on IT use, and the adaptation of the law to new UITU. All the codes that emerged from this phase were labeled first-order codes.

Our second phase consisted of axial coding, where we sought to establish linkages across the first-order codes with the objectives of ascribing first-order codes to second-order codes and gaining a better understanding of causal links between the concepts in context. Both objectives were informed by our theoretical framework. Indeed, while ascribing first-order 
codes to second-order codes, we used broad categories of the cost-benefit analysis, such as benefit, cost, or risk of being caught. Our interpretation of the causal links between concepts was also informed by RCT reasoning: we were able to make sense of our informants' statements based on how they related to the cost-benefit analysis. This approach provided us with an initial understanding of the causal links between variables. We were also attentive to divergences between actors and thus to which mechanisms were salient in different groups of actors' interpretations. At this stage, it became clear which mechanisms were identified by all actors, a majority of buyers, a majority of suppliers, or mainly buyers or suppliers.

Our third phase consisted of selective coding, where all the second-order codes were grouped into aggregated dimensions. This enabled us to provide strong explanations for the observed links between the aggregated dimensions. This process served the emergence of a new framework (Corbin and Strauss, 2008), comprised of empirically embedded propositions and insights.

During the data analysis phase, two of the three researchers were involved in the coding operations. There were extensive and frequent discussions between all the researchers on the coding outcomes (categorizing, eliminating, merging, etc.). This approach enabled us to conciliate contradictory interpretations and to consolidate our propositions into a meaningful framework that gave a nuanced answer to the research question. However, we were conscious that the analysis of data emanating from interpretive research is not confined to facts but also involves the respondents' and researchers' own subjectivities (Walsham, 1995). We addressed this challenge in two ways. First, our data analysis explicitly recognized and highlighted any possible tension between our informants' interpretations. Second, we provided an appropriate rationale each time we noticed any tension between and/or within our groups of informants.

Moreover, in view of our interpretive epistemological approach, we focused on identifying the presence of codes and their potential relationships. We did not search for frequencies of occurrence, as qualitative research is concerned primarily with analyzing the meaning of the constructs emanating from the empirical results (Van Maanen, 1979). With the abstraction principle in mind (Klein and Myers, 1999), our study drew on Walsham's (1993) argument that the legitimacy of inferences extracted from one case does not hinge upon statistical representativeness, but rather relies "on the plausibility and cogency of the logical reasoning used in describing the results from the cases, and in drawing conclusions from them" (p. 15). At the same time, Table A2 provides a detailed explanation of the validity of our interpretive approach according to the criteria mobilized by the seven principles of the seminal paper by Klein and Myers (1999).

Finally, in order to strengthen our contribution to theory, we generated theoretical propositions that draw specific implications. In a recent review of case study usage in the information systems literature, Tsang (2014) argued that this approach is consistent with the meaning of generalization. In line with the reasoning method used by interpretive scholars such as Geertz (1973) and Van Maanen (1983), we thus went beyond our informants' firstlevel descriptions to generalize second-order constructs.

\section{Results}

Our data analysis shows that three dimensions of legal intervention - the formalization of UITU and its associated costs, the visibility of IT use and the amplification of the effect on the organization's reputation - helped to influence the cost-benefit analysis determining the 
decision to commit UITU. Importantly, these three dimensions triggered differentiated responses from the two main categories of actors concerned: the potential victims and those who might benefit from UITU. In addition, our data analysis showed that the legal intervention gave rise to unexpected effects on IT use, which included triggering new UITU and the discontinuance of IT use.

\section{Formalization of UITU and associated costs}

Formalization clarifies what constitutes UITU and its associated costs when the offender is caught. This can affect the cost-benefit analysis by dissipating ambiguity when an offense has been committed and increasing its perceived cost. However, while suppliers tend to share this view, there is little consensus between buyers.

The legal intervention formalized the meaning of UITU by defining precisely what constitutes the latter and clarifying the severe sanctions associated with such offenses:

In addition to the obligation to pay damages, the Law also lays down severe prison sentences (2 years) and fines $(€ 30,000)$ for price manipulation concerning reverse e-auctions, especially if the price manipulation takes place through one of the following means:

- by disseminating deceptive or libelous information by any means;

- by introducing onto the market or soliciting either offers intended to trouble the market prices, or unbalanced high or low bids in relation to the prices asked by the sellers or service providers;

- by adopting any other fraudulent means.

Any attempted price manipulation is subject to the same (Dutreil Law, Appendix C).

Interestingly, institutional actors and lawyers were aware that existing general legislation could actually provide adequate sanctions. However, as noted in an EU report, "Although national legal rules apply to unfair commercial practices in B2B e-markets, their existence and enforceability is not obvious to the e-market actors" (Van Eekce and Skouma, 2006, p. 144). Lawyers and institutional actors involved in the crafting of the law agreed with this statement, suggesting that "marketplaces often don't realize that this law applies to them" (Lawyer). Thus, while the intrinsic cost of an offense has not necessarily been affected, what has changed is the perception of such costs by potential offenders.

Suppliers highlighted the fact that formalization clarified the meaning of UITU: "the law draws the attention of actors to a precise point [...]. The law has been published and will make the actors better informed and more vigilant" (Supplier). Consequently, these IT users are now more aware of what is ethically acceptable or not, and are thus able to identify the risks associated with such behaviors. The suppliers also considered that the clarification of the costs associated with UITU dramatically changed the stakes for potential offenders, thereby mitigating UITU: "The risks are enormous, and sanctions, penalties, and fines are not neutral, notably in sensitive periods. I think now that an actor who respects this and does not want to incur risks in running their business will necessarily abide by the law" (Supplier). Overall, suppliers perceive a dissuasive effect associated with formalization because it reduces ambiguity and increases perceived costs. Notwithstanding this perception, we noted a sense of regret on the supply side concerning the lack of timeliness of the intervention: "If we had had this from the start, we would have avoided so many abuses" (Supplier).

Some buyers also acknowledge the importance of formally clarifying the nature and meaning of UITU. The new legislation formalized what was legal and what was not in precise and context-specific terms that applied directly to the case of ORAs. This reduced the ambiguity 
surrounding UITU: "When a legal text is passed, you read it and it shows you the way. It's no longer a rumor that guides your interpretation of events" (Buyer). Further, some buyers were aware of the limits of the business code both in terms of defining UITU and the sanctions, and formalization helped to remedy this limitation: "Yes, a code of ethics does not suffice to tell here is what you need to do in order to be good. Since there are no possible sanctions, obviously it does not solve the entire problem" (Buyer). However, other reactions from buyers illustrated a different perspective. In particular, many insisted that formalization, while useful, did not in itself really mitigate the risk of UITU: "Yes, I think it is good in any case, to have a framework, I mean for anything you need a framework. This being said, even with the law, I don't think this prevented people from cheating, to do fake auctions with a participant who would be some sort of fake bidder." (Buyer).

Our findings show divergent views of the potential impact of formalization on the cost-benefit analysis between buyers and suppliers. Most suppliers recognize the role of formalization in influencing the meaning and cost of UITU. Buyers, on the other hand, have differing views of the role played by formalization. While some consider that formalization reduces the ambiguity of UITU and increases perceived costs, many state that it does not influence behaviors. This suggests that formalization is likely to impact on the cost-benefit analysis in relation to some, but not all, buyers. Our results lead to the following proposition:

Proposition 1: Formalization of the nature of UITU and its associated sanctions will only affect the cost-benefit analysis of individual IT users who perceived an ambiguity in the definition of UITUs and associated sanctions.

\section{Visibility of IT use}

Our data revealed the importance of visibility as a key mechanism that affects the potential offender's cost-benefit analysis. The intervention created visibility by introducing the obligation to trace all transactions, together with increased control over IT use. Visibility affects the cost-benefit analysis by increasing IT users' awareness of the risk of being caught.

The lawyers we interviewed stressed the importance of IT use controls as a mechanism within the legal intervention that influence the cost-benefit analysis associated with UITU; interestingly, they underlined how such controls rely on a clear definition of UITU: "Now, the rules are written into a law pertaining to the use of auctions. This means that the authorities can control the use of auctions and that the buyers will no longer want to put themselves in an illegal position" (Lawyer). Yet, controls are only possible, or at least are much more feasible if concrete traces of the transactions exist. This is why the law sets out strict guidelines about keeping a trace of IT use: "The buyer or the person organizing the auction records the auction's progress and stores the data for a period of at least one year" (Dutreil Law). This creates suitable conditions for watchdog agencies to run audits and controls and thus detect UITU ex-post: "Users can erase their emails by deleting them. However, we can still see what has been destroyed over a long period of time" (Institutional). As part of the intervention, the watchdog agencies use their legal leverage to implement more frequent and systematic controls: "The legislation, the obligation for transparency and our annual control plans have helped us to obtain better knowledge of retailers, suppliers and abusive practices. Thus, as time goes on, I think that it has obliged all users to tighten up their practices and to abandon others" (Institutional).

Suppliers embraced this vision and were fully convinced of the importance of keeping traces of such IT transactions in order to change the cost-benefit analysis and thus mitigate UITU: 
"Having to register the bidding event engages the retailer to something ethical that will be traced in a written way so he must be careful" (Supplier). Another supplier emphasized the latent nature of the sanctions that deters UITU. "You will be guaranteed that is to say, you know very well that there is a sword of Damocles hanging over your head if you do anything" (Supplier). Suppliers also consider that the enactment of controls is a strong dissuasive mechanism: "It's evident that the fear of controls by the authorities is a major element for us" (Supplier). There is a clear perception by most suppliers of the importance of tracing transactions in order to ensure tighter control. They agree that it increases the risks perceived by buyers and facilitates control. The very existence of extended controls is thus perceived as a deterrent against UITU. However, some suppliers add nuance to this perspective, arguing that they are unlikely to request controls themselves because of the power asymmetry that prevails between buyers and suppliers: "If a supplier is suspected of calling for controls, the buyers will exclude him as a form of revenge" (Supplier).

Buyers concur with suppliers in stressing the impact of visibility on the cost-benefit analysis: "When we know that we are controlled and this can be the subject of verification and that there are financial sanctions, it is evident that vigilance will be increased and that we won't behave like others do" (Buyer). Another buyer noted the importance of enhanced visibility on refraining from engaging in UITU "Today there is total transparency, there is an authority that controls and everything is visible. Thanks to the system, there is no way to cheat. I think that no one will take the risk at this point because it's so easy to get caught...it would be suicidal to play with this."

Interventions by the watchdog agency based on the traces of IT use are mentioned as clear examples of the power granted to the agency by the law, dissuading buyers from opting for UITU due to the increased risk of being caught: "A couple of years ago, the authorities came to our headquarters and took 25 PCs. It is true that they have the power of moralization since they can say if you do not respect the law, you will be punished. They couldn't do it before but now they can" (Buyer). Interestingly, they also mention the risk of denunciation by suppliers: "You know when we organize a bidding event with ten suppliers, if you are embarrassed in this event; there are at least nine suppliers who risk denouncing you" (Buyer). Buyers thus clearly perceive an increased risk of being prosecuted due to the heightened visibility of IT use enabled by the tracing of transactions and the enhanced control that this affords.

Both suppliers and buyers interpret the visibility of IT use as a deterrent against UITU, as it increases the risk that offenders will be discovered. However, buyers tend to put more emphasis on the risks associated with denunciation by suppliers. Our analysis of the role of visibility leads us to our second proposition:

Proposition 2: The more legal intervention increases the visibility of IT use through the combination of IT use and ex-post controls, the greater the likelihood that individual IT users will perceive a high risk of being caught and will thus refrain from engaging in UITU.

\section{Amplification of the impact on the organization's reputation}

The impact of a discovered offense on an organization's reputation is bolstered by the media exposure associated with the intervention, thus increasing the reputational cost of an offence for the offender's organization. Since this affects the cost of transgression for the organization, it makes UITU less appealing. 
This aspect of intervention was clearly identified by the institutional actors, lawyers and IT initiators, who explained the importance of the reputational effect for offending organizations. The watchdog agency systematically exploited cases of positive controls by leveraging the media. For instance, one technology initiator highlighted reputation as a significant risk linked to UITU: "You can't stop actors who suffer from these transgressions from speaking up and consequently you run a risk. First, you're not clean about your ethics and then you run a risk in terms of image, and this is tremendously important for companies" (IT initiator).

While suppliers did not refer spontaneously to this reputational effect, buyers' representatives indicated that they considered this effect as one of the major costs for the company if caught: "We work in markets where you finally have fewer and fewer players and more and more large corporations. If we discover that someone or other is cheating, this will lead to a loss of trust, a boomerang effect and media exposure that will harm the organizations concerned" (Buyer). Buyers were well aware of the reputational aspect of the intervention. They explained that this organizational effect is of a high magnitude, since its repercussions extend well beyond a fine for a specific unethical practice, and can affect the entire company, particularly if the media coverage is strengthened by a systematic institutional campaign: "There are also media drawbacks in which the government plays a large part. It means that if one big actor from the retail side or the supply side commits a small transgression, you'll have your name vilified in all the media and this is more expensive than a fine" (Buyer).

The reputational effect, especially when amplified by institutional actors, was clearly perceived as a key element of the higher cost associated with legal intervention by the buyer, affecting their cost-benefit analysis. It was not a major element in the suppliers' responses regarding UITU, however. Thus, our analysis of the role played by reputation in the costbenefit calculus leads us the following proposition:

Proposition 3: The more the legal intervention amplifies the reputational effects associated with UITU, thus creating a reputational risk for the organization, the higher the cost of UITU and thus the higher the likelihood that IT users will refrain from engaging in UITU.

\section{Emergent effects of intervention on IT use and adaptability of the intervention}

Notwithstanding the previous effects of the intervention in terms of cost-benefit analysis, our data analysis also showed the existence of emergent and unexpected impacts on IT use. At first, IT users, especially buyers, attempted to negotiate their way around the intervention by exploiting loopholes in the law. This led to an amendment of the legal intervention. Our data also showed that in response to the complexity introduced by the intervention, some users chose to reduce or discontinue ORA use.

Some of the buyers attempted to circumvent the intervention with respect to its timeframe and scope. For instance, the legal intervention doubled the deadline required for notice of a contract's termination if the latter was made at the end of an online bidding event. Buyers tried to bypass the time constraints introduced by the intervention by sending a confirmation letter and a termination letter simultaneously at the start of the transaction: "I mean they've decided that they'll send a termination letter to the supplier so that the contract will be cancelled one year after its start date in such a way as to announce the notice immediately, and to double it in line with the law [...] but in fact, it's kind of skirting around the law" (ORA Coordinator). Buyers also tried to negotiate the scope of the intervention by shifting the 
location of the online bidding event to another jurisdiction: "A retailer who is present in numerous countries with adapted logistical circuits can organize the bidding event in Germany or Spain, and then send the goods involved in the auction to France" (Buyer). Suppliers acknowledged the risk that buyers could bypass the law: "in all cases, they end up managing to dodge the law for one simple reason, namely that we need the buyers, whereas they just need to buy" (Supplier). This interpretation was confirmed by another buyer, who confessed that there was a systematic determination to discover the extent to which the intervention could be negotiated by circumventing the law. "After the law was passed, we spent some time figuring out what we could do to get round it" (Buyer). There is thus strong evidence that buyers actively attempted to maintain some of the practices targeted by the law, and also developed some new UITU such as asking suppliers to sign immediate termination letters to avoid the increased term of notice. This analysis leads us to the following proposition.

Proposition 4a: The more IT users discover loopholes in the legal intervention, the higher the likelihood that they will attempt to get round it by adapting their practices.

The legislator understood the need to endow the intervention with the potential to evolve in line with stakeholders' ability to dodge it. Thus, reacting to attempts to bypass it, the legislator adapted the law. First, the price that offenders would have to pay in the event that they were caught cheating rose significantly from $€ 30,000$ to $€ 2$ million. Second, the scope of the intervention was changed to apply to any product sold in France, regardless of the country in which the IT was being used: "The reverse auction venue can easily be moved and is therefore not significant. Accordingly, the applicable law is the law where the prejudice occurred, in other words, the law of the place where the supplier incurs prejudice" (Second legal intervention, No. 303, Page 20557, Clause No. 123; see Appendix D).

Our analysis of the emergence of new UITUs and the resulting adaptation of the law leads us to the following proposition:

Proposition 4b: Because IT users alter their practices on an ongoing basis; intervention against UITU is likely to trigger new UITU, resulting in the need for further intervention.

Simultaneously, our results revealed that the intervention had some emergent and unexpected effects on IT use. Some buyers took the extreme position of simply not using the technology because of the increased complexity resulting from formalization: "It's true that the number of auctions has decreased. Because of the law, they're getting harder to organize" (Buyer). Others pointed to a decline in the use of ORAs, acknowledging that the reduction in IT use was due to the growing complexity of organizing online bidding events: "ORA use is decreasing [...], the mission of the buyer is becoming more complex because the request for quotations has to be solid, very precise, and the selected suppliers have to be really comparable" (Suppliers).

Proposition 5a: When attempting to mitigate UITU, legal interventions can result in increased complexity of technology use, thus leading to the limitation or discontinuance of IT use.

Buyers also argued that since visibility creates a perceived risk of control, it also contributes to a reduction in the use of the technology. This was confirmed by the ORA Coordinator who 
organizes all the bidding events for the buyers at the retailer's head office. Thus, he confirmed the discontinuance of ORA use, attributing it to the significant increase in the new risks associated with the technology's use: "we're really concerned that even though we did our job properly, the supplier will complain, triggering new investigations that no one will appreciate; it's a real concern for us to deal with [...]; all these regulations increase the risk. We do everything we can to avoid it, especially as using ORAs increases the chances of an investigation. So we organize fewer ORAs to avoid the risk" (ORA Coordinator). Suppliers shared a similar interpretation since they said they had witnessed a significant decrease in ORA use. They suggested that the enhanced intervention led to a decline in willingness to use the IT because of its complexity. For instance, one supplier indicated: "I have seen the regression in terms of auction use ...this is explained by the heightened degree of complexity in the buyers' job because they need to display ultra-correct use of the technology" (Supplier).

Proposition 5b: By attempting to mitigate UITU, the legal intervention can result in an increase in the perceived risk of technology use, thus leading to the limitation or discontinuance of IT use.

Our findings show the extent to which intervention should not be seen as a static endeavor, but rather, should be considered as a dynamic and systematic effort that needs to be adapted to the way IT users negotiate the IT artifact. It can result in unexpected effects such as new UITUs and limitation or discontinuance of use.

\section{Discussion}

In this section, we build on our findings to discuss our propositions and suggest research avenues that deal with UITU. Our results show that the legal intervention can influence the cost-benefit analysis which determines the decision to commit UITU through three main mechanisms: formalization, visibility of IT use, and amplification of the reputational effect. We theoretically discuss the contribution of these mechanisms and the associated propositions and consequences of this in terms of intervention. Table 2 below summarizes the findings of our study and the links with the propositions. We discuss below the main elements that constitute our findings: the three mechanisms through which intervention operates - namely formalization, visibility and amplification of the reputational effect, the new UITU and adaptability of the intervention, and the emergent effect on IT use.

Table 2. Main findings and propositions

\begin{tabular}{|c|c|c|c|c|}
\hline \multirow{2}{*}{$\begin{array}{l}\text { Mechanisms } \\
\text { associated } \\
\text { with the legal } \\
\text { intervention }\end{array}$} & \multicolumn{2}{|c|}{ IT Users } & \multirow[b]{2}{*}{ Confrontation } & \multirow[b]{2}{*}{ Propositions } \\
\hline & Buyers & Suppliers & & \\
\hline \multirow[t]{2}{*}{$\begin{array}{l}\text { Mitigation of } \\
\text { UITU through } \\
\text { the } \\
\text { formalization } \\
\text { of UITU and } \\
\text { associated } \\
\text { costs }\end{array}$} & $\begin{array}{l}\text { Some buyers suggest } \\
\text { that formalization can } \\
\text { affect the cost-benefit } \\
\text { analysis since it } \\
\text { clarifies UITU and its } \\
\text { implications. } \\
\text { However, other } \\
\text { buyers challenge this, } \\
\text { suggesting that } \\
\text { formalization does } \\
\text { not constitute a strong } \\
\text { deterrent. }\end{array}$ & $\begin{array}{l}\text { The majority of } \\
\text { suppliers think that } \\
\text { formalization of UITU } \\
\text { and its associated } \\
\text { sanctions will result in } \\
\text { deterring UITU as it } \\
\text { lifts the ambiguity of } \\
\text { such behavior and } \\
\text { changes the buyers' } \\
\text { perception of the cost if } \\
\text { caught. }\end{array}$ & $\begin{array}{l}\text { Divergent } \\
\text { interpretations } \\
\text { between the buyers } \\
\text { and the suppliers. }\end{array}$ & Proposition 1 \\
\hline & Buyers indicate that & Suppliers are & Convergent & \\
\hline
\end{tabular}




\begin{tabular}{|c|c|c|c|c|}
\hline $\begin{array}{c}\text { Mitigation of } \\
\text { UITU through } \\
\text { the visibility } \\
\text { of IT use }\end{array}$ & $\begin{array}{l}\text { visibility impacts on } \\
\text { the cost-benefit } \\
\text { analysis as it } \\
\text { increases the risk of } \\
\text { being caught. }\end{array}$ & $\begin{array}{l}\text { convinced that tracing } \\
\text { IT use will affect the } \\
\text { buyers' cost/benefit } \\
\text { analysis. }\end{array}$ & $\begin{array}{l}\text { interpretations } \\
\text { between buyers and } \\
\text { suppliers of the role } \\
\text { of visibility as the } \\
\text { latter acts as a latent } \\
\text { mechanism that } \\
\text { influences the cost- } \\
\text { benefit analysis }\end{array}$ & Proposition 2 \\
\hline $\begin{array}{l}\text { Mitigation of } \\
\text { UITU through } \\
\text { amplification } \\
\text { of the effect } \\
\text { on the } \\
\text { organization's } \\
\text { reputation }\end{array}$ & $\begin{array}{l}\text { Buyers interpret the } \\
\text { effect on } \\
\text { organizational } \\
\text { reputation as an } \\
\text { important factor that } \\
\text { affects the cost- } \\
\text { benefit analysis. }\end{array}$ & $\begin{array}{l}\text { Suppliers do not refer } \\
\text { spontaneously to the } \\
\text { reputation mechanism. }\end{array}$ & $\begin{array}{l}\text { Convergent } \\
\text { interpretations of the } \\
\text { amplification of the } \\
\text { reputation } \\
\text { mechanism among } \\
\text { buyers. }\end{array}$ & Proposition 3 \\
\hline $\begin{array}{l}\text { New UITU } \\
\text { and } \\
\text { adaptability } \\
\text { of the } \\
\text { intervention }\end{array}$ & $\begin{array}{l}\text { Buyers recognize } \\
\text { attempts to create } \\
\text { new UITU by } \\
\text { bypassing the } \\
\text { intervention (e.g., } \\
\text { dodging the } \\
\text { conditions of its } \\
\text { application). }\end{array}$ & $\begin{array}{l}\text { Suppliers believe that } \\
\text { buyers will always try } \\
\text { to find ways to bypass } \\
\text { interventions because } \\
\text { of their economic } \\
\text { power over suppliers. }\end{array}$ & $\begin{array}{l}\text { Convergent } \\
\text { interpretations from } \\
\text { buyers and suppliers } \\
\text { about the } \\
\text { adaptability of the } \\
\text { intervention despite } \\
\text { referring to different } \\
\text { rationales. }\end{array}$ & $\begin{array}{l}\text { Proposition 4a } \\
\text { Proposition 4b }\end{array}$ \\
\hline $\begin{array}{c}\text { Emergent } \\
\text { effect on IT } \\
\text { use }\end{array}$ & $\begin{array}{l}\text { Buyers point to the } \\
\text { decline in IT use } \\
\text { because of the } \\
\text { growing complexity } \\
\text { and risks caused by } \\
\text { the intervention }\end{array}$ & $\begin{array}{l}\text { Suppliers confirm the } \\
\text { decrease in IT use } \\
\text { because of the growing } \\
\text { complexity for the } \\
\text { buyers. }\end{array}$ & $\begin{array}{l}\text { Convergent } \\
\text { interpretations from } \\
\text { buyers and suppliers } \\
\text { about the decline in } \\
\text { IT use. }\end{array}$ & $\begin{array}{l}\text { Proposition 5a } \\
\text { Proposition 5b }\end{array}$ \\
\hline
\end{tabular}

First, our results show that there are two aspects to formalization: clarification of the nature of UITUs and enunciation of the sanctions associated with these UITUs. Our findings indicate that the majority of suppliers and some buyers consider that formalization affects the costbenefit analysis of buyers and is therefore a potential deterrent to UITUs.

For actors who agree that this is the case, formalization is interpreted as clarifying the meaning of UITU, thus reducing ambiguity about offending acts; it also clarifies the cost incurred when an offender is caught, thus increasing the perceived cost of offenses. As formalization refers to the process of codifying and enforcing input, output and behaviors (Ouchi, 1979), it can facilitate IT users' sense-making by clarifying the ethical standards associated with IT use, which has been shown as an important driver of ethical behaviors in a broader context (Kaptein, 2008). According to Vlaar et al. (2006), such formalization helps to demarcate what is acceptable and what is not in a specific context.

At the same time, we know that RCT accepts that actors' assessments and resulting choices are made on the basis of imperfect information which introduces uncertainty into the RCT calculus (Cornish and Clarke, 1986; Nagin, 1998). Formalization has the merit of lifting part of the definitional ambiguity surrounding UITU and the associated sanctions. There is thus a strong theoretical rationale to support the idea that it can change the individual perception of the costs and benefits associated with the transgression that triggered a change in the course of actions (Becker, 1993), thus mitigating the UITU. 
However, in our case, this impact on the cost-benefit analysis was only perceived by some of the buyers. There are two possible explanations for the lack of perceived impact of formalization by some buyers. First, the key utility of formalization is its informative function for buyers who were unaware of the types of sanctions they could incur and for which uses of the technology. It is thus quite possible that buyers who were more knowledgeable about UITU and the associated sanctions according to non-specific regulations were less affected by the clarification. Second, one of the key effects of the formalization was clarification of the gravity of the sanctions incurred. Indeed, the RCT theory deems sanctions to be an appropriate instrument with which to deal with deviant behaviors (Nagin and Paternoster, 1993) since higher stakes are associated with deviant behaviors (Paternoster and Pogarsky, 2009). Thus, the combined effect of definitional clarification and stronger sanctions is likely to mitigate the cost-benefit analysis determining UITU. However, there is evidence from the IS literature that the severity of sanctions is not a key deterrent to UITU compared to threat appraisal (Pahnila et al., 2007; Li et al., 2010). This could explain why the clarification of the level of such sanctions was less of a deterrent for a certain number of buyers who were already aware of the risk of sanctions.

The theoretical discussion of our results thus suggests a clear delineation of the effect of formalization on the perceived risk of sanctions, and the effect of the perceived gravity of sanctions. Concretely, we suggest that formalization can influence the cost-benefit analysis of actors who perceived an ambiguity in the definition of UITUs, and thus in the risk of sanctions. In view of our findings and the emerging literature in IS, lifting the ambiguity of the gravity of sanctions might be less of a deterrent than previously supposed. This is important since it partly contradicts the prediction of RCT according to which increasing the perceived level of sanctions would have a stronger impact on the cost-benefit analysis. While these emerging results need to be quantitatively tested, they open up interesting research avenues to qualify the relative impact of the variables included in the cost-benefit analysis conducted by potential offenders.

Second, our case study also indicates that the visibility of IT use can affect the cost-benefit analysis by buyers, thereby contributing to UITU mitigation. This interpretation was shared by both buyers and suppliers. In our context, visibility corresponds to the creation of records of the transactions and increased risks of controls. This naturally affects buyers' calculations, since it increases the ex-ante perception of the risk of being caught. The information systems literature has already recognized the importance of visibility-defined as the creation of records - in making a decision regarding IT adoption (Karahanna et al., 1999; Moore and Benbasat, 1991) but without linking it to UITU mitigation. Our data shows that the continuous tracing of IT use plays an important role in mitigating UITU as it directly increases the risk of being identified. Visibility is also increased by the risk of controls that will leverage the records made. This is consistent with the conclusions drawn by other scholars in the context of illegal Internet use, where the likelihood of detection was found to be a strong deterrent for UITU (Li et al., 2010).

Our findings indicate that the combination of tracing records of IT use and ex-post controls creates a situation, specific to the context of IT use, in which actors combine the risk of being caught in the act with that of being caught ex-post over an extended period of time. This clearly affects their cost-benefit analysis, increasing the perceived risk of being caught and thus providing a strong deterrent against UITU.

A third mechanism contributing to the mitigation of UITU is that of the amplification of the 
reputational effect. This emanates from the communication outcomes linked to the intervention, leading to a higher reputational cost for the offenders' organization. Our findings show that the costs associated with UITU can extend beyond the scope of the individual offender to that of his/her organization, resulting in a negative reputational effect. Amplification of the reputational effect arising from negative media exposure would therefore result in a higher cost for the offender's reputation. The business ethics literature confirms that the company's reputation in general is fundamental to its image (Gray and Balmer, 1998) and to attracting quality partners (Fombrun and Shanley, 1990), and that this is particularly true from the vantage point of its buyer/supplier relationships (Bendixen and Abratt, 2007).

This is understandable, as the management literature has shown that unethical corporate acts have a detrimental effect on the quality of the organization's network in terms of exchange partners. They alter the quality and the structure of the network: quality because the firm loses ground in terms of reputation, size and profitability, and structure because its legitimacy is undermined (Sullivan et al., 2007). Organizations that enjoy a good reputation also find that the latter plays a role as a substitute for costly governance mechanisms (Williamson, 1996). It follows that by amplifying the reputational effect, the law provides a deterrent that existing mechanisms such as codes of conduct could not offer. We know that business codes have limited efficacy, often because employees are unaware of their existence, because they conflict with sub-group norms (Harrington, 1996), or because they come second to efficient operations in employees' estimation (Healy and Iles, 2002). Given the extensive publicity associated with the amplification of the reputational effect and the potential negative impact on key organizational assets such as brands and operating costs, a legal intervention will inevitably go beyond the limitations of business codes. Amplification of the reputational effect is likely to be a strong deterrent to UITU since it provides such a major incentive to organizations that host the potential offenders.

Fourth, our results also demonstrate a paradox between two opposing results associated with intervention. Indeed, while we found that intervention was able to influence the cost-benefit analysis associated with UITU mitigation, we also discovered that it triggered the emergence of new forms of UITU. We know that IT users are social actors who dynamically and continuously negotiate their use of the technology (Lamb and Kling, 2003) and update their sense-making (Jasperson et al., 2005) and IT practices accordingly (Lamb and Kling, 2003). Our findings show that this negotiation of the technology can paradoxically trigger unexpected new cases of UITU. In our case, buyers tried to circumvent the law by adapting their use to exploit any available loophole. This situation prompted the legislator to intervene again in order to address the remaining gaps in the legislation. This finding highlights the paradox that can exist between the intentions of a legal intervention and the way IT users deal with it.

In the information systems literature, Robey and Boudreau (1999) show that IT use can be associated with paradoxes or polarized pairs of outcomes such as organizational flexibility and organizational rigidity. For the authors, paradoxes create a tension between two or more apparently incongruous statements (decline in UITU and emergence of new types of UITU in our case). According to Robey and Boudreau (1999), the "acknowledgment of paradox can stimulate theory-building by provoking creative insights that accommodate seemingly opposite positions" (p. 169). In order to deal with such paradoxes, Robey and Boudreau (1999) suggest that the integration of contingency variables could lead to resolving the tension emanating from the paradoxes. Our findings suggest that any intervention that deals with UITU needs to be adapted to IT users' new means of getting round it by being flexible and 
ready to deal with the negotiation of the IT and the associated new UITU.

Another emergent result is that while intervention is perceived as able to mitigate UITU, it can also have an unexpected effect in terms of the diminution or discontinuance of IT use. The increased constraints on IT use - complexity of the rules, tracing, controlling and risk of sanctions - makes some buyers less likely to continue their use of the technology.

We also observed that the intervention increased the transaction costs (Williamson, 1975) associated with the use of the technology and altered buyers' expectations of it (Bhattacherjee, 2001), which led to a decline in use or its discontinuance. More specifically, we know that in their early days, ORAs were particularly appealing to buyers; they were presented as an easyto-use type of technology that could generate significant and rapidly available advantages by considerably enhancing purchasing performance and shortening the negotiation cycle (Smart and Harrison, 2003). However, the intervention dramatically shifted buyers' perceptions of the technology from simple to complex. Buyers highlighted the complexity of the process and the burdensome preparatory work, which corresponded to an increase in transaction costs. The legal intervention also created the perception of ORAs as a risky endeavor, and one in which any mistake would be deemed an UITU that could lead to high individual and organizational costs.

Finally, using the general principles of RCT, this means that buyers developed a new calculus, where they compared the benefits of IT use with the 'new' organizational and individual costs introduced by the legal intervention. While former research in other contexts has shown how intervention can trigger IT use (Liang et al., 2007; Purvis et al., 2001; Rodon et al., 2011), we found that the effect of the intervention targeted at mitigating UITU is much less straightforward, particularly when it changes the expected outcome of an IT's use. This provides a sound theoretical explanation for the effect that we observed on the use of the IT in question in our study: buyers believed that the costs and risks generated by the new constraints arising from the intervention outweighed the expected advantages associated with it, and were therefore tempted to limit or even discontinue its use. Thus, by introducing transaction costs that outweighed the perceived comparative benefit of ORAs to alternative solutions, the intervention led to the limitation or discontinuance of use. This finding contrasts with widespread views on intervention in IS where it is only considered in its capacity to promote IT use, without consideration for the possible negative impact in terms of technology discontinuation. In effect, intervention in the IS literature has mainly been associated with positive outcomes such as effective electronic communication (Orlikowski et al., 1995), technological adaptation (Tyre and Orlikowksi, 1994) or interorganizational systems assimilation (Rodon et al., 2011). Neglecting this potential 'dark side' of legal intervention puts future interventions at risk of unexpected side effects on IT use. While we offer a first insight into the issue, further research is needed regarding the negative effects of intervention on IT use.

\section{Conclusion}

The aim of this study was to understand how legal intervention could mitigate UITU by influencing the cost-benefit analysis determining the decision to commit such UITU. This is especially important in view of previous evidence according to which business codes implemented by management and third parties are inefficient in dealing with UITU (Harrington, 1996; Healy and Iles, 2002), as well as the damaging effects of UITU on organizations and society more broadly. To this end, we examined the case of a legal 
intervention specifically designed for ORAs, a highly controversial technology from an ethical standpoint.

Our contribution is twofold. First, we provide testable propositions on the mechanisms through which legal intervention can impact UITU by affecting the cost-benefit analysis, and we discuss its complex and paradoxical effects on UITU and IT use more generally. Second, we offer an innovative take on intervention, according to which the latter is conceived and should be researched as a dynamic, multi-mechanism process that can adapt to UITU as well as to evolutions in IT use.

First, the set of propositions depicts a complex and paradoxical picture of how legal intervention can impact UITU and IT use more generally. When we embarked upon our research, we expected to observe two types of mechanisms: some which would alter the costbenefit calculus determining the decision to commit UITU and some which would not. Instead, we encountered a far more intricate situation, in which the law has a differentiated and complex effect on use, with some unexpected consequences. While some of the mechanisms have the potential to alter IT users' cost-benefit analysis to ultimately mitigate existing UITU, others can trigger new cases of UITU or discontinuance of use. This can be likened to the type of polarized outcomes deemed paradoxical by Robey and Boudreau (1999). It is only by understanding these differentiated and complex mechanisms that legal intervention can be improved. Therefore, instead of looking for black and white effects, unintended outcomes need to be added to the equation in order to adopt a more flexible and supple approach to intervention.

Second, our results offer an innovative take on intervention in general, whereby the latter may be conceived as a dynamic multi-mechanism process that can adapt to both UITU and to evolutions in IT use. Our case study shows that the combination of various mechanisms is a key element in targeting diverse groups of users and stakeholders. We thus suggest that intervention should go beyond the unique instrument of sanctions. In effect, a combination of mechanisms can extend the impact of intervention in time and scope. Visibility, as defined in our case by the combination of records and ex-post controls, can increase the temporal horizons of potential sanctions, thus impacting on the risk of being caught in the future and accordingly affecting the cost-benefit analysis. The temporal dimension associated with visibility thus appears as an important dimension to take into account when working on intervention, especially in the context of IT use, where keeping records and analyzing such traces is made easier by the technologies themselves.

Increasing the reputational effect could extend the scope of the intervention, creating an incentive for organizations and their members to prioritize mitigation of UITUs since such behavior increases their reputational and, potentially, their operational costs. This could encourage organizations to create stronger ex- ante organizational mechanisms that would be deeply embedded in the organizational culture, supporting the intervention, and thus being more efficient then existing business codes. We see this as a promising research avenue on remedies to UITU.

Our findings also show that intervention should be considered as a dynamic process, continually adapting to the users' negotiation of the technology. Our study improves our understanding of intervention in general by exploring how users' adaptation and interventions shape one another through use. Our research thus acknowledges the fact that IT is an evolving system embedded in a complex and dynamic social context (Orlikowksi and Iacono, 2001). In 
such a fast evolving environment as IT use, adaptability is a key success factor for intervention. Since emergent and unexpected effects could occur as users circumvent the technology, IT managers and management should understand that intervention is not a oneshot process but needs to be designed in a flexible and evolving manner, conceived as a process rather than as a one-off act. We thus suggest that intervention should integrate the following criteria: articulating ex-ante and ex-post mechanisms, anticipating changes in UITU and IT use, and combining individual and organizational deterrents. These parameters constitute interesting research avenues for IS scholars seeking to explore organizational responses to UITU.

Our findings have important implications for practitioners crafting intervention. Our distinction between the three mechanisms impacting on the cost-benefit analysis can be used as a basis for practice. Practitioners should take into account how these different mechanisms may be interpreted by various groups of stakeholders, and subsequently integrate the impact of intervention both on UITU and more generally on IT use, as well as developing a dynamic approach to intervention. Practitioners need to craft proactive intervention practices in line with the principles captured in our propositions. This is crucial in contexts where ubiquitous digital technologies involving unprecedented numbers of actors are continuously developing, as in the case of social media-related technologies.

One of the limitations of this study is that our conclusions are based on the interpretation of actors on how the cost-benefit analysis will be conducted by potential offenders. While we interviewed actors that were directly concerned by the issue and our propositions are backed up by our empirical findings, it was beyond the scope of this study to measure the actual impact of intervention on the evolution of UITU. This would require the collection of quantitative data over an extended period of time, something that would certainly be a worthwhile endeavor for future research.

In addition, because they emanate from a single case study in a specific context, our propositions would need to be tested in different contexts and in relation to different technologies, types of UITU, and forms of intervention before being generalized. We are confident that our general results - portraying intervention as a multi-mechanism dynamic process that can adapt to the evolution of UITU and IT use - is likely to be operative in other IT settings and for other forms of intervention; this is particularly true given the dynamic nature of IT and IT use.

However, there is still much to learn about specific combinations of mechanisms and their sequences in different contexts and in relation to different groups of stakeholders. In particular, research could explore discontinuation further by investigating in more detail which actors choose to discontinue use in which context. It would also be fruitful to use other experimental designs in order to test our propositions. We also propose testing our propositions in relation to other forms of intervention that directly or indirectly influence the RCT calculus associated with UITU, whether it is within or between organizations. Another related topic would be to explore the extent to which these different forms of intervention complement one another. Finally, more exploratory research is also needed on the modi operandi of various forms of intervention.

\section{References}

Atkinson, W., 2003. New buying tools present different ethical challenges. Purchasing 132 (4), 27-29. 
Beall, S., Carter, C., Carter, P.L., Germer, T., Hendrick, T., Jap, S., Kaufmann, L., Maciejewski, D., Monczka, R., Petersen, K., 2003. The role of reverse auctions in strategic sourcing. Research Paper. Center for Advanced Purchasing Studies (CAPS).

Becker, G.S., 1993. Nobel lecture: The economic way of looking at behavior. Journal of Political Economy 101 (3), 385-409.

Bendixen, M., Abratt, R., 2007. Corporate identity, ethics and reputation in supplier-buyer relationships. Journal of Business Ethics 76 (1), 69-82.

Berente, N., Younglin, Y. 2012. Institutional contradictions and loose coupling: Postimplementation of NASA's enterprise information system. Information Systems Research 23 (2), 376-396.

Bhattacherjee, A., 2001. Understanding information systems continuance: An expectationconfirmation model. MIS Quarterly 25 (3), 351-370.

Bommer, M., Gratto, C., Gravander, J., Tuttle, M., 1987. A behavioral model of ethical and unethical decision making. Journal of Business Ethics 6 (4), 265-280.

Bulgurcu, B., Cavusoglu, H., Benbasat, I., 2010. Information security policy compliance: An empirical study of rationality-based beliefs and information security awareness. MIS Quarterly 34 (3), 523-548.

Bush, V., Bush, A.J. Orr, L., 2010. Monitoring the ethical use of sales technology: An exploratory field investigation. Journal of Business Ethics 95 (2), 239-257.

Charki, M.H. Josserand, E., 2008. Online reverse auctions and the dynamics of trust. Journal of Management Information Systems 24 (4), 175-197.

Charki, M.H., Josserand, E., Boukef, N., 2011. Toward an ethical understanding of the controversial technology of online reverse auctions. Journal of Business Ethics 98(1), 1737.

Chase, S.E., 2011. Narrative inquiry: Still a field in the making. In: Denzin, N.K., Lincoln, Y.S. (Eds.), The sage handbook of qualitative research. Thousand Oaks, CA: Sage, pp. 421-434.

Chatterjee, S., 2005. A model of unethical usage of information technology. The Americas Conference on Information Systems Proceedings.

Chatterjee, S., Valacich, J.S., Sarker, S., 2012. Unethical use of information technology: A two-country study. Paper presented at the $45^{\text {th }}$ Hawaii International Conference on System Sciences.

Corbin, J., Strauss, A. 2008. The basics of qualitative research, third ed. Sage, Los Angeles, CA.

Cornish, D.B., Clarke, R.V., 1986. The Reasoning Criminal: Rational Choice Perspectives on Offending. Springer-Verlag, New York.

Daly, S.P., Nath, P., 2005. Reverse auctions for relationship marketers. Industrial Marketing Management 34 (2), 157-166.

D'Arcy, J., Hovav, A., Galletta, D., 2009. User awareness of security countermeasures and its impact on information systems misuse: A deterrence approach. Information Systems Research. 20 (1), 79-98.

Denzin, N.K., Lincoln, Y.S., 2011. Introduction: The discipline and practice of qualitative research. In: N.K. Denzin ; Y.S. Lincoln (Eds.), The sage handbook of qualitative research fourth edition. Sage, Thousand Oaks, CA.

Dickson-Swift, V., James, E.L., Kippen, S., Liamputtong, P., 2009. Researching sensitive topics: Qualitative research as emotion work. Qualitative Research 9 (1), 61-79.

Emiliani, M., 2005. Regulating B2B online reverse auctions through voluntary codes of conduct. Industrial Marketing Management 34 (5), 526-534.

Fombrun, C., Shanley, M. 1990. What's in a name? Reputation building and corporate strategy. Academy of Management Journal 33 (2), 233-258. 
Gattiker, U.E., Kelley, H., 1999. Morality and computers: Attitudes and differences in moral judgments. Information Systems Research 10 (3), 233-254.

Geertz, C., 1973. The Interpretation of Cultures: Selected Essays. Basic Books, New York.

Giampietro, C., Emiliani, M., 2007. Coercion and reverse auctions. Supply Chain Management: An International Journal 12 (2), 75-84.

Grasmick, H.G., Bursik Jr., R.J., 1990. Conscience, significant others, and rational choice: Extending the deterrence model. Law and Society Review 24 (3), 837-861.

Gray, B., 2008. Intervening to improve inter-organizational partnerships. In: Cropper S., Ebers M., Huxham Ch., Smith R. (Eds.), The Oxford Handbook of Inter-Organizational Relations. Oxford, England, Oxford University Press, pp. 666-690.

Gray, E.R., Balmer, J.M.T., 1998. Managing corporate image and corporate reputation. Long Range Planning 31 (8), 695-702.

Grogger, J., 1991. Certainty vs. severity of punishment. Economic Inquiry 29 (2), 297-309.

Harrington, S.J., 1996. The effect of codes of ethics and personal denial of responsibility on computer abuse judgments and intentions. MIS Quarterly 20 (3), 257-278.

Healy, M., Iles, J., 2002. The establishment and enforcement of codes. Journal of Business Ethics 39 (1-2), 117-124.

Henfridsson, O., Lind, M. 2014. Information systems strategizing, organizational subcommunities, and the emergence of a sustainability strategy. Journal of Strategic Information Systems 23 (1), 11-28.

Hirschheim, R., Klein H., Lyytinen K., 1995. Information Systems Development and Data Modeling: Conceptual and Philosophical Foundations. Cambridge University Press, Cambridge, UK, New York and Melbourne.

Hur, D., Mabert, V.A., Hartley, J.L., 2007. Getting the most out of reverse e-auction investment. Omega 35 (4), 403-416.

Jap, S.D., 2003. An exploratory study of the introduction of online reverse auctions. Journal of Marketing 67 (3), 96-107.

Jap, S.D., 2007. The impact of online reverse auction design on buyer-supplier relationships. Journal of Marketing 7 (1), 146-159.

Jasperson, J., Carter, P.E., Zmud, R.W., 2005. A comprehensive conceptualization of postadoptive behaviors associated with information technology enabled work systems. MIS Quarterly 29 (3), 525-557.

Johnson, D.G., Mulvey, J.M., 1995. Accountability and computer decision systems. Communications of the ACM. 38(12), 58-64.

Jones, T.M., 1991. Ethical decision making by individuals in organizations: An issuecontingent model. Academy of Management Review 16 (2), 366-395.

Kaptein, M., 2008. Developing a measure of unethical behavior in the workplace: A stakeholder perspective. Journal of Management 34 (5), 978-1008.

Karahanna, E., Straub, D.W., Chervany, N.L., 1999. Information technology adoption across time: A cross-sectional comparison of pre-adoption and post-adoption beliefs. MIS Quarterly 23 (2), 183-213.

Klein, H.K., Myers, M.D., 1999. A set of principles for conducting and evaluating interpretive field studies in information systems. MIS Quarterly 23 (1), 67-93.

Lamb, R., Kling, R., 2003. Reconceptualizing users as social actors in information systems research. MIS Quarterly 27 (2), 197-236.

Leonard, L.N., Cronan, T.P., 2001. Illegal, inappropriate, and unethical behavior in an information technology context: A study to explain influences. Journal of the Association of Information Systems 1 (1), 1-31 
Leonard, L.N., Cronan, T.P., Kreie, J., 2004. What influences IT ethical behavior intentionsplanned behavior, reasoned action, perceived importance, or individual characteristics? Information \& Management 42 (1), 143-158.

Li, H., Zhang, J., Sarathy, R., 2010. Understanding compliance with internet use policy from the perspective of rational choice theory. Decisions Support Systems 48 (4), 635-645.

Liang, H., Saraf, N., Hu, Q., Xue, Y., 2007. Assimilation of enterprise systems: The effect of institutional pressures and the mediating role of top management. MIS Quarterly 31 (1), $59-87$.

McCarthy, B., 2002. New economics of sociological criminology. Annual Review of Sociology 28 (1), 417-442.

Mason, R.O., 1986. Four ethical issues of the information age. MIS Quarterly 10 (1), 5-12.

Miles, M.B., Huberman, A.M., 1994. Qualitative data analysis: An expanded sourcebook. Sage, Thousand Oaks, CA.

Moore, G.C., Benbasat, I., 1991. Development of an instrument to measure the perceptions of adopting an information technology innovation. Information Systems Research 2 (3), 192222.

Moores, T.T., Chang, J.C.J., 2006. Ethical decision making in software piracy: Initial development and test of a four-component model. MIS Quarterly 30 (1), 167-180.

Morse, J.M., 2004. Theoretical saturation. In Michael S. Lewis-Beck, Alan Bryman \& Tim Futing Liao ed., Encyclopedia of social science research methods, Sage Publications. Thousand Oaks, CA.

Myers, M.D., Avison, D., 2002. Qualitative research in information systems: A reader. Sage.

Myers, M.D., Newman, M., 2007. The qualitative interview in IS research: Examining the craft. Information and Organization 17 (1), 2-26.

Nagin, D.S., 1998. Criminal deterrence research at the outset of the twenty-first century. Crime and Justice 23, 1-42.

Nagin, D.S., Paternoster, R., 1993. Enduring individual differences and rational choice theories of crime. Law Sociology Review 27 (3), 467-496.

Orlikowski, W.J., Baroudi; J.J., 1991. Studying information technology in organizations: Research approaches and assumptions. Information Systems Research 2 (1), 1-28.

Orlikowski, W.J., Iacono, C.S., 2001. Research commentary: Desperately seeking the "IT" in IT research: A call to theorizing the IT artifact. Information Systems Research 12 (2), 121134.

Orlikowski, W.J., Yates, J., Okamura, K., Fujimoto, M., 1995. Shaping electronic communication: the metastructuring of technology in the context of use. Organization Science 6 (4), 423-444.

Ouchi, W.G., 1979. A conceptual framework for the design of organizational control mechanisms. Management Science 25 (9), 833-848.

Oz, E., 1992. Ethical standards for information systems professionals: A case for a unified code. MIS Quarterly 16 (4), 423-433.

Pahnila, S., Siponen, M., Mahmood, A., 2007. Employees' behavior towards IS security policy compliance. $40^{\text {th }}$ Hawaii International Conference on System Sciences.

Paternoster, R., Bachman, R., 2001. Explaining Criminals and Crime: Essays in Contemporary Criminological Theory. Roxbury Publishing Company, Los Angeles.

Paternoster, R., Pogarsky, G., 2009. Rational choice, agency and thoughtfully reflective decision making: The short- and long-term consequences of making good choices. Journal of Quantitative Criminology 25 (2), 103-127.

Paternoster, R., Simpson, S., 1996. Sanction threats and appeals to morality: Testing a rational choice model of corporate crime. Law Sociology Review 30 (3), 549-583. 
Payne, D., Landry, B.J., 2005. Similarities in business and IT professional ethics: The need for and development of a comprehensive code of ethics. Journal of Business Ethics 62 (1), 73-85.

Piquero A.R., Hickman, M., 2002. The Rational Choice Implications of Control Balance Theory. In: Piquero, A.R., Tibbetts, S.G. (Eds.), Rational Choice and Criminal Behavior, Routledge, New York, pp. 85-107.

Pratt, M.G., 2009. From the editors: For the lack of a boilerplate: Tips on writing up (and reviewing) qualitative research. Academy of Management Journal 52 (5), 856-862.

Purvis, R.L., Sambamurthy, V., Zmud, R.W., 2001. The assimilation of knowledge platforms in organizations: An empirical investigation. Organization Science 12 (2), 117-135.

Racherla, P., Mandviwalla, M., 2013. Moving from access to use of the information infrastructure: A multilevel sociotechnical framework. Information Systems Research 24 (3), 709-730.

Richards, L., 1999. Using NVivo in qualitative research. Bundoora, Victoria, Australia.

Robey, D., Boudreau, M.C., 1999. Accounting for the contradictory organizational consequences of information technology: Theoretical directions and methodological implications. Information Systems Research 10 (2), 167-185.

Rodon, J., Sese, F., Christiaanse, E., 2011. Exploring users' appropriation and postimplementation managerial intervention in the context of industry IOIS. Information Systems Journal 21 (3), 223-248.

Sarker, S., Sarker, S., Sahaym, A., Bjørn-Andersen, N. 2012. Exploring value cocreation in relationships between an ERP vendor and its partners: a revelatory case study. MIS Quarterly 36 (1), 317-338.

Seidel, S., Recker, J., Vom Brocke, J., 2013. Sensemaking and sustainable practicing: Functional affordances of information systems in green transformations. MIS Quarterly 37 (4), 1275-1299.

Siponen, M., Vance, A., 2010. Neutralization: New insights into the problem of employee information systems security policy violations. MIS Quarterly 34 (3), 487-502.

Smart, A., Harrison, A., 2003. Online reverse auctions and their role in buyer-supplier relationships. Journal of Purchasing and Supply Management 9 (5), 257-268.

Straub, D.W., Nance, W.D., 1990. Discovering and disciplining computer abuse in organizations: A field study. MIS Quarterly 14 (1), 45-62.

Stylianou, A., Winter, S., Niu, Y., Giacalone, R.M., 2013. Understanding the behavioral intention to report unethical information technology practices: The role of Machiavellianism, gender, and computer expertise. Journal of Business Ethics 117 (2), 333-343.

Sullivan, B.N, Haunschild, P., Page, K., 2007. Organizations non gratae? The impact of unethical corporate acts on interorganizational networks. Organization Science 18 (1), 55 70.

Tassabehji, R., Taylor, W., Beach, R., Wood, A., 2006. Reverse e-auctions and supplier-buyer relationships: An exploratory study. International Journal of Operations and Production Management 26 (2), 166-184.

Tsang, E.W.K., 2014. Case studies and generalization in information systems research: A critical realist perspective. Journal of Strategic Information Systems 23 (2), 174-186.

Tyre, M.J., Orlikowski, W.J. 1994. Windows of opportunity: Temporal patterns of technological adaptation in organizations. Organization Science 5 (1), 98-118.

Van Eecke, P., Skouma G., 2006. European Commission Study: B2B e-marketplaces: A legal analysis of unfair trade practices within the European Union, European Commission Study ENTR/04/69, Brussels. 
Van Maanen, J., 1979. Reclaiming qualitative methods for organizational research: A preface. Administrative Science Quarterly 24 (4), 520-526.

Van Maanen, J., 1983. Qualitative Methodology. Sage, Beverly Hills, CA.

Vlaar, P.W.L, Van den Bosch, F.A.J., Volberda, H.W., 2006. Coping with problems of understanding in interorganizational relationships: Using formalization as a means to make sense. Organization Studies 27 (11), 1617-1638.

Walsham, G., 1993. Interpreting Information Systems in Organizations. John Wiley and Sons, New York.

Walsham, G., 1995. Interpretive case studies in IS research: Nature and method. European Journal of Information Systems 4 (2), 74-81.

Williamson, O. E., 1975. Markets and Hierarchies: Analysis and Antitrust Implications. The Free Press, New York.

Williamson, O.E., 1996. The Mechanisms of Governance. Oxford University Press, Oxford. 


\section{APPENDICES}

\section{Appendix A}

Table A1. Groups of informants and their adaptation to the research question

\begin{tabular}{|c|c|c|}
\hline $\begin{array}{l}\text { Categories of } \\
\text { informants }\end{array}$ & Sampling details & Rationale for inclusion in the study \\
\hline $\begin{array}{l}\text { IT users who were } \\
\text { blamed for UITU } \\
\text { (Buyers) }\end{array}$ & $\begin{array}{l}\text { Twenty-nine buyers: } 26 \text { buyers and } 3 \\
\text { buyers' managers }\end{array}$ & $\begin{array}{l}\text { Buyers represent the stakeholders who benefit the most } \\
\text { from the UITU. Buyers were identified as the party with } \\
\text { the greatest responsibility for UITU. }\end{array}$ \\
\hline $\begin{array}{l}\text { IT users who } \\
\text { suffered from } \\
\text { UITU } \\
\text { (Suppliers) }\end{array}$ & Twenty-two suppliers & $\begin{array}{l}\text { Suppliers are providers of industrial goods who are pre- } \\
\text { selected by the buyers to take part in the online bidding } \\
\text { event. They represent the stakeholders who benefit the } \\
\text { least from the technology's use. The legal intervention } \\
\text { introduced new clauses to protect them from potential } \\
\text { UITU. }\end{array}$ \\
\hline \multirow{5}{*}{$\begin{array}{l}\text { Institutional } \\
\text { actors who } \\
\text { intervened to deal } \\
\text { with UITU }\end{array}$} & $\begin{array}{l}\text { Vice President of the French Competition } \\
\text { Authority }\end{array}$ & \multirow{2}{*}{$\begin{array}{l}\text { The Competition Authority and the Directorate for } \\
\text { Competition Policy are the two main institutions that } \\
\text { regulate business relationships. They were involved in } \\
\text { the design of the legal intervention. }\end{array}$} \\
\hline & $\begin{array}{l}\text { Legal representative of the General } \\
\text { Directorate for Competition Policy, } \\
\text { Consumer Affairs and Fraud Control }\end{array}$ & \\
\hline & $\begin{array}{l}\text { The Economic Expert within the General } \\
\text { Directorate for Competition Policy, } \\
\text { Consumer Affairs and Fraud Control }\end{array}$ & $\begin{array}{l}\text { The Directorate for Competition Policy asked an } \\
\text { economic expert to estimate the outcomes linked to } \\
\text { UITU. }\end{array}$ \\
\hline & $\begin{array}{l}\text { A representative of the Examination } \\
\text { Commission of Good Business Practices }\end{array}$ & $\begin{array}{l}\text { Due to UITU, the first two institutions asked the } \\
\text { commission to investigate the extent to which the use of } \\
\text { ORAs was consistent with ethics. }\end{array}$ \\
\hline & $\begin{array}{l}\text { The legal representative studying the legal } \\
\text { appropriation of ORAs (the mandate for } \\
\text { the study was undertaken by the } \\
\text { Examination Commission of Good } \\
\text { Business Practices) }\end{array}$ & $\begin{array}{l}\text { The Examination Commission of Good Business } \\
\text { Practices asked a legal expert in business relationships to } \\
\text { investigate the extent to which ORA use was in line with } \\
\text { the French law. }\end{array}$ \\
\hline $\begin{array}{l}\text { The technology } \\
\text { initiators who } \\
\text { designed and } \\
\text { deployed the } \\
\text { technology whose } \\
\text { use led to UITU }\end{array}$ & $\begin{array}{l}\text { Manager of the B2B Projects \& } \\
\text { Organization } \\
\text { Sales Manager for B2B Applications } \\
\text { ORA Coordinator } \\
\text { NeoGrid (ex-Agentrics) Senior Sourcing } \\
\text { Manager }\end{array}$ & $\begin{array}{l}\text { The role of the technology initiators was to promote, } \\
\text { convince, and support the use of all e-procurement } \\
\text { technologies (including ORAs) by buyers and suppliers. } \\
\text { The technology initiators were the first supporters of the } \\
\text { ORAs technology. }\end{array}$ \\
\hline \multirow{2}{*}{$\begin{array}{l}\text { Lawyers who have } \\
\text { expertise } \\
\text { associated with } \\
\text { UITU } \\
\text { (particularly in } \\
\text { the case of ORAs) }\end{array}$} & $\begin{array}{l}\text { The lawyer was mandated by the } \\
\text { European Commission to investigate } \\
\text { unethical behavior within European B2B } \\
\text { Electronic Market Places }\end{array}$ & $\begin{array}{l}\text { Due to the frequency of UITU at the European level, the } \\
\text { European commission mandated an international legal } \\
\text { expert in the judicial investigations of the ethical issues } \\
\text { linked to ORA use. We interviewed the lawyer who was } \\
\text { responsible of assembling the different feedback of the } \\
\text { legal experts. }\end{array}$ \\
\hline & $\begin{array}{l}\text { Two European legal experts in the } \\
\text { treatment of affairs linked to B2B } \\
\text { technologies such as B2B ORAs }\end{array}$ & $\begin{array}{l}\text { These experts were directly involved in cases related to } \\
\text { UITU. }\end{array}$ \\
\hline
\end{tabular}


Table A2. Research assessment according to the seven principles of interpretive studies (Klein and Myers, 1999)

\begin{tabular}{|c|c|c|}
\hline $\begin{array}{l}\text { The principles of } \\
\text { interpretive research } \\
\text { (Klein and Myers, 1999) }\end{array}$ & Definition & Application to our interpretive research \\
\hline $\begin{array}{l}\text { 1. The fundamental } \\
\text { principle of the } \\
\text { hermeneutic circle }\end{array}$ & $\begin{array}{l}\text { Achieving a permanent iteration between the } \\
\text { interdependent meaning of parts and the whole they } \\
\text { form. }\end{array}$ & $\begin{array}{l}\text { Our case study satisfied this principle in two ways. First, we iterated between the detailed } \\
\text { account of concrete manifestations of the intervention and its mitigation of UITU and the } \\
\text { broader context of IT use. Second, RCT served as an interpretive framework to articulate our } \\
\text { propositions, thus supporting our rationale. Third, the approach to coding directly allows for } \\
\text { the progressive consolidation of first order codes into aggregated dimensions. }\end{array}$ \\
\hline $\begin{array}{l}\text { 2. The principle of } \\
\text { contextualization }\end{array}$ & $\begin{array}{l}\text { Use of critical thinking regarding the social and } \\
\text { historical background to the research so as to give the } \\
\text { reader a sense of the way the current situation has } \\
\text { emerged. }\end{array}$ & $\begin{array}{l}\text { We paid special attention to the context in which the intervention was taking place. This was } \\
\text { achieved in particular through the collection of extensive documentation before beginning } \\
\text { the study. In the method section, we present the context to help the reader contextualize our } \\
\text { results and propositions. }\end{array}$ \\
\hline $\begin{array}{l}\text { 3. The principle of } \\
\text { interaction between the } \\
\text { researchers and the } \\
\text { subjects }\end{array}$ & $\begin{array}{l}\text { Critical reflection on how the research materials and } \\
\text { data were socially constructed through interactions } \\
\text { between the researchers and participants. }\end{array}$ & $\begin{array}{l}\text { This research was the second collaboration between the first researcher and the retail } \\
\text { organization. The first collaboration occurred between June } 2005 \text { and April } 2006 \text {. This } \\
\text { facilitated an understanding of the actors' discourse based on inter-subjectivity. However, } \\
\text { only one other researcher was also involved in coding. This means that a critical perspective } \\
\text { of the social construction of the research material was achieved through discussions between } \\
\text { the three researchers, who each had a different level of engagement with the participants. }\end{array}$ \\
\hline $\begin{array}{l}\text { 4. The principle of } \\
\text { abstraction and } \\
\text { generalization }\end{array}$ & $\begin{array}{l}\text { Relating idiographic details revealed by data } \\
\text { interpretation through the application of principles one } \\
\text { and two to theoretical, general concepts that describe } \\
\text { the nature of human understanding and social action. }\end{array}$ & $\begin{array}{l}\text { The researchers made a significant effort to design an ensemble of empirically embedded } \\
\text { propositions linked to the expected and emergent effects of intervention on UITU. To do } \\
\text { this, the researchers relied on an iterative process integrating the data and the theoretical } \\
\text { insights gained from the RCT. }\end{array}$ \\
\hline $\begin{array}{l}\text { 5. The principle of } \\
\text { dialogical reasoning }\end{array}$ & $\begin{array}{l}\text { Revelation of possible contradictions between the } \\
\text { theoretical preconceptions guiding the research design } \\
\text { and the actual findings with subsequent cycles of } \\
\text { revision. }\end{array}$ & $\begin{array}{l}\text { While the general principles of RCT were respected, the scope of its application and the } \\
\text { results observed were in part unexpected. We were able to move beyond our preconception } \\
\text { of the expected results thanks to our approach to coding, the first stage of which was open } \\
\text { coding. }\end{array}$ \\
\hline $\begin{array}{l}\text { 6. The principle of } \\
\text { multiple interpretations }\end{array}$ & $\begin{array}{l}\text { Identification of any difference in interpretation within } \\
\text { or between the groups of interviewees as they can be } \\
\text { expressed in multiple narratives or stories of the same } \\
\text { sequence of events under study. }\end{array}$ & $\begin{array}{l}\text { It is acknowledged that data analysis that emanates from interpretive research is not confined } \\
\text { to facts but also involves the researchers' own subjectivity; hence, it includes the } \\
\text { researchers' interpretations of other people's interpretations (Walsham, 1995). We tackled } \\
\text { this in two ways. Our data analysis explicitly recognized and highlighted any possible } \\
\text { tensions between the interpretations made by our informants. Such tensions led us to a } \\
\text { nuanced interpretation of the answers to our research question. }\end{array}$ \\
\hline $\begin{array}{l}\text { 7. The principle of } \\
\text { suspicion }\end{array}$ & $\begin{array}{l}\text { Identification of plausible biases and systematic } \\
\text { distortions in the narratives collected from the } \\
\text { participants. }\end{array}$ & $\begin{array}{l}\text { We gathered multiple narratives from different informants in each category of actors, but } \\
\text { also across categories (i.e., not only buyers and suppliers but also IT initiators, institutional } \\
\text { actors, and lawyers). The IT users' interpretations were thus contrasted with the } \\
\text { interpretations of the other groups of informants, but also in relation to other informants from } \\
\text { the same group. The researchers also discussed the findings with the key informants and with } \\
\text { peers from the academic field. }\end{array}$ \\
\hline
\end{tabular}




\section{Appendix B}

\section{Table B1. Codes used for data analysis}

\begin{tabular}{|c|c|c|}
\hline First-order codes & \begin{tabular}{|l} 
Second-order codes \\
\end{tabular} & Aggregated dimensions \\
\hline Formalization of UITU & \multirow{2}{*}{$\begin{array}{l}\text { Formalization of the meaning of UITU } \\
\text { Formalization of the costs of UITU }\end{array}$} & \multirow{3}{*}{ Formalization } \\
\hline $\begin{array}{c}\text { Framework of reference; meaning of UITU; } \\
\text { sanctions; costs }\end{array}$ & & \\
\hline $\begin{array}{l}\text { Enforceability; legal grounds; risks of sanction; } \\
\text { generic sanctions }\end{array}$ & Perceived cost & \\
\hline $\begin{array}{c}\text { Information; attention; meaning; } \\
\text { interpretation/rumor }\end{array}$ & Ambiguity of UITU & \multirow[t]{2}{*}{ Visibility } \\
\hline $\begin{array}{l}\text { Being seen; transparency; control plans; tracing } \\
\text { transactions }\end{array}$ & Tracing IT use; controlling IT use & \\
\hline $\begin{array}{c}\text { Mediatization; reputational effect; vilification; } \\
\text { loss of trust; risk of being caught; incentives; } \\
\text { organizational costs }\end{array}$ & Amplification of the reputational effect & Reputational effect \\
\hline $\begin{array}{l}\text { Cheating; abusive practices geographic loophole; } \\
\text { temporal loophole }\end{array}$ & Negotiation of IT use & New UITU \\
\hline $\begin{array}{c}\text { Revision of the cost the offender will pay when } \\
\text { caught } \\
\text { Revision of the scope of the intervention }\end{array}$ & Revision of the intervention & $\begin{array}{l}\text { Adaptability of the } \\
\text { intervention }\end{array}$ \\
\hline $\begin{array}{l}\text { Difficulty to organize ORAs; complexity; risks } \\
\text { of controls }\end{array}$ & \multirow[t]{3}{*}{ Discontinuance of IT use } & \multirow[t]{3}{*}{ IT use } \\
\hline Decrease of IT use & & \\
\hline Limitation of IT use & & \\
\hline
\end{tabular}




\title{
Appendix C
}

\section{First legal intervention}

\author{
No. 0179, Page 12639, Clause No. 2
}

“- I. A contract is not valid (...) in the event that the organized reverse e-auction has not respected one of the following principles:

1. Preliminary to the auction, the buyer or the person organizing the auction communicates in a transparent way, and without any discrimination, to all the candidates allowed to bid for the determining elements of the products or services he/she seeks to obtain, the purchasing terms and conditions, the detailed selection criteria, as well as the rules applying to the auction;

2. At the end of the auction period, the identity of the selected supplier shall be disclosed at the request of any candidate who has participated in the auction;

- II. The buyer or the person organizing the auction shall register the progress of the auction and shall store the data for a period of one year. The buyer can be represented in the event that an investigation is carried out, under the conditions foreseen in section $\mathrm{V}$ of the Commercial Code;

- III. Reverse e-auctions organized by a buyer or by his/her representative are prohibited in the case of agricultural products (...) and staple food products resulting from an initial transformation of these products;

- IV. Not respecting provisions I to III engages the responsibility of the offender and obliges him/her to repair the damage caused (...)

In addition to the obligation to pay damages, the law also lays down severe prison sentences (2 years) and fines (up to $€ 30,000$ ) for price manipulation in reverse e-auctions, especially if the price manipulation takes place in one of the following ways:

- by diffusing, via any means, deceptive or libelous information;

- by introducing into the market or soliciting either offers intended to trouble the market prices, or unbalanced high or low bids, in relation to the prices requested by the sellers or service providers;

- by using any other fraudulent means; any attempted price manipulation is subject to the same sanctions." 


\section{Appendix D}

\section{Second legal intervention}

No. 303, Page 20557, Clause No. 123

"Article L. 442-10 of the Commercial Code sanctions by nullity all contracts organized through remote reverse auctions, including by electronic means, and that do not meet any one of the formal rules prescribed in this article.

Article L. 442-6 (I, 5) of the Code sets the minimum period of notice in case of abrupt termination of business relationships resulting from a competition by distance auction at twice that resulting from applying the same paragraph where the duration of the initial notice is less than six months, and at least one year in all other cases. Any infringement of this rule shall incur the civil liability of the offender and expose him or her to a fine of 2 million euros in accordance with paragraph III of Article L. 442-6 of the Commercial Code.

The relocation of platforms organizing ORAs in remote sites outside the country raises the issue of law enforcement in space. Regarding the liability of the buyer or the person who arranges the auction on his/her behalf, it is necessary to consult the applicable case law. Thus, the law of the place of prejudice shall apply in such cases (Lautour, civ. May 25, 1948). In the case of dissociation between the event and the injury, the place of prejudice covers both that where the damage was generated and the place where the damage occurred (Civ. I, May 11, 1999). The reverse auction venue can easily be moved and is therefore not significant. Accordingly, the applicable law is the law where the prejudice occurred, in other words, the law of the place where the supplier incurs prejudice. Moreover, if the nullity of contracts does not meet the requirements of Article L. 442-10 of the Commercial Code, then it falls within the domain of criminal. This applies to all contracts that are intended to supply a buyer with goods for resale in France.

If the revocation or civil liability proceedings are brought before a civil or commercial court by the Minister of Economy in accordance with paragraphs III and IV of Article L. 442-6 of the Code, the offender's business organization shall incur a fine of two million euros. Article L. 443-2 criminalizes the act of operating the artificial lowering of the price of goods or services by introducing on the market or soliciting offers below the prices charged by vendors or service providers." 